\title{
К 70-ЛЕТИЮ ПРОФ. В. И. НАЙДЕНКО
}

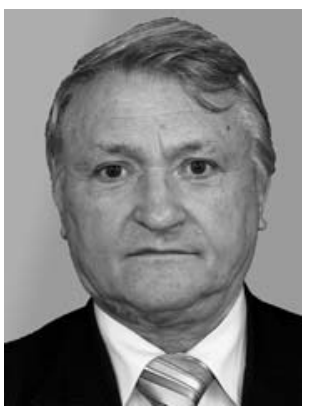

6 февраля 2011 г. исполнилось 70 лет видному специалисту в области электродинамики периодических структур, доктору физико-математических наук, профессору кафедры теоретических основ радиотехники НТУУ «КПИ» Найденко Виктору Ивановичу. В 1963 г. он с отличием окончил радиотехнический факультет Киевского политехнического института и поступил в аспирантуру на кафедру теоретических основ радиотехники КПИ. В 1970 году защитил кандидатскую диссертацию, а в 1993 - докторскую диссертацию.

Проф. В. И. Найденко внес существенный вклад в теорию и практику периодических структур для электронных приборов и ускорителей заряженных частиц, в принципы построения электронных приборов с управлением амплитудой, фазой и поляризацией сигнала. Исследовал свойства полей и энергетических характеристик на границах полос пропускания периодических структур и вблизи них. Предложил, развил теорию и ввел в практику несколько новых методов измерения энергетических характеристик периодических структур. Основываясь на дифракционных подходах, развил теорию известных методов измерений энергетических характеристик периодических структур, повысив их информационные возможности и точность. Разработал и внедрил в промышленность и сельскохозяйственное производство и медицину, технологичные энергетические микроволновые установки.
В. И. Найденко - автор более 250 научных работ, в том числе 25 изобретений, 4 монографий, 1 учебного пособия. Под его руководством подготовлено 4 кандидата наук.

Виктор Иванович - член обществ «IEEE Electron Devices Society», «IEEE Microwave Theory and Techniques Society», «IEEE Antenna and Propagation Society» (США) с 1995 г. С января 2003 г. Senior Member IEEE. Организатор Workshор-97 «Микроволновые технологии и установки 97», поддержанного IEEE EDs, IEEE APs, IEEE MTTs (США). Председатель оргкомитета Международной конференции «Mathematical Methods in Electromagnetic Theory», 2002, 2010 НТУУ «КПИ», г. Киев. Заслуженный изобретатель СССР.

Проф. В. И. Найденко - член редакционной коллегии международного журнала «Известия высших учебных заведений. Радиоэлектроника», ответственный редактор журнала «Правове, нормативне та метрологічне забезпечення системи захисту інформації в Україні», заместитель председателя специализированного ученого совета Д 26.002.26, был членом специализированных ученых советов Д 26.005.02, Д 26.005.05, К 03.044.03.

В. И. Найденко - Лауреат II премии КПИ (1987 г.) за монографию «Аксиально-симметричные периодические структуры и резонаторы» (написанную в соавторстве с Ф. Ф. Дубровкой), академик Международной академии информатизации. Публикуется в известных журналах Украины, России, США.

Ректорат НТУУ «КПИ», члены редакционной коллегии журнала «Изв. вузов. Радиоэлектроника», сотрудники РТФ, кафедры ТОР и редакции журнала сердечно поздравляют Виктора Ивановича с 70-летием и желают ему крепкого здоровья и дальнейших творческих успехов в его научной и педагогической деятельности. 